\title{
O True Apothecary: How Forensic Science Helps Solve a Classic Crime
}

Amanda S. Harper-Leatherman

Fairfield University, aharper@fairfield.edu

John R. Miecznikowski

Fairfield University, jmiecznikowski@fairfield.edu

Follow this and additional works at: https://digitalcommons.fairfield.edu/chemistry-facultypubs Copyright 2012 The American Chemical Society

This is the author's pre-print version of a work that was submitted for publication. A definitive version of the article was published in Journal of Chemical Education 2012, 89(5), 629-635. DOI: 10.1021/ed200289t

\section{Repository Citation}

Harper-Leatherman, Amanda S. and Miecznikowski, John R., "O True Apothecary: How Forensic Science Helps Solve a Classic Crime" (2012). Chemistry \& Biochemistry Faculty Publications. 13.

https://digitalcommons.fairfield.edu/chemistry-facultypubs/13

\section{Published Citation}

Harper-Leatherman, A.;* Miecznikowski, J.R. "O True Apothecary: How Forensic Science Helps Solve a Classic Crime." Journal of Chemical Education, 2012, 89 (5), 629-635.

This item has been accepted for inclusion in DigitalCommons@Fairfield by an authorized administrator of DigitalCommons@Fairfield. It is brought to you by DigitalCommons@Fairfield with permission from the rightsholder(s) and is protected by copyright and/or related rights. You are free to use this item in any way that is permitted by the copyright and related rights legislation that applies to your use. For other uses, you need to obtain permission from the rights-holder(s) directly, unless additional rights are indicated by a Creative Commons license in the record and/or on the work itself. For more information, please contact digitalcommons@fairfield.edu. 


\title{
O True Apothecary: How Forensic Science Helps Solve a Classic Crime
}

\author{
Amanda S. Harper-Leatherman* and John R. Miecznikowski \\ Fairfield University, Department of Chemistry \& Biochemistry, \\ 1073 North Benson Road, Fairfield, CT 06824
}

\begin{abstract}
As part of a university-wide project to explore Shakespeare's classic play, Romeo and Juliet, from a variety of perspectives, we presented an interdisciplinary talk to our university community on the chemistry of the potions and poisons referenced in Romeo and Juliet. To draw our multidisciplinary audience in and to teach about forensics as well as pharmaceutical herbs and chemicals, our presentation was given from the perspective of how a modern crime scene investigator would approach the famous play's final death scene without any prior knowledge of the situation. We described how if an autopsy of Juliet's body had been done, it might have revealed the presence of the chemicals, hyoscine and atropine, that come from the plant, Atropa belladonna. The autopsy could reveal whether or not the Friar had truly set out to sedate Juliet, or if he had attempted to kill her. An autopsy of Romeo's body might have revealed the presence of aconitine from the plant, Aconitum napellus. Through this approach of using a classic story to teach about chemistry, we were able to introduce basic ideas about forensics and pharmacology, emphasizing the importance of dose when determining the effect of a drug on the human body.
\end{abstract}

\section{KEY WORDS}

General Public, Interdisciplinary/Multidisciplinary, Public Understanding/Outreach, MultimediaBased Learning, Forensic Chemistry, Nonmajor Courses, Toxicology

\section{AUDIENCE}

Content for Everyone Interested in Chemical Sciences 


\title{
O True Apothecary: How Forensic Science Helps Solve a Classic Crime
}

\author{
Amanda S. Harper-Leatherman* and John R. Miecznikowski \\ Fairfield University, Department of Chemistry \& Biochemistry, \\ 1073 North Benson Road, Fairfield, CT 06824
}

\section{MANUSCRIPT TEXT}

In April 2010, Fairfield University produced Shakespeare's classic play, Romeo and Juliet. This production marked the end of what was known at the University as the ' $R$ \& J Project,' a yearlong multidisciplinary exploration of the many themes in Romeo and Juliet (1). The project sponsored film showings, discussions, and faculty lectures on topics related to Romeo and Juliet such as love, the family, the Renaissance, music, and religious life. These events were open to the entire university. As one of the project events, the R \& J Project head asked us to give a general interest talk on the potions and poisons referenced in Romeo and Juliet. The director was especially interested in the sleeping potion given to Juliet by the Friar and whether this type of potion was purely fictional or not.

After researching the topic, we decided to present our findings to our multidisciplinary university audience in an entertaining way by considering the final death scene of Romeo and Juliet from a crime scene investigator's perspective. This report outlines our interdisciplinary presentation and the pedagogical approach we took in this one lecture to introduce our primarily non-science audience to forensics and pharmaceutical herbs and chemicals through the story of Romeo and Juliet. A pdf version of our power point presentation can be found in the online Supporting Information. Although we presented just one lecture, there are many ways that instructors may use this material or that this material may be integrated into the curriculum. For instance, this material could be expanded and used as a unit on Shakespearean herbalism in 
either a non-science majors course or a theatre class. Considering a familiar story with a death scene, such as Romeo and Juliet, from a crime scene investigator's perspective might also be a good way to introduce basic ideas about analyzing a crime scene to an introductory forensic science class. This material could be used to enhance a discussion of toxicology in a forensics course as well. Using stories to teach scientific principles is not a new concept and has been written about as a pedagogical technique in past $J C E$ issues (2-5).

To begin our approach to presenting this material, as a one-hour presentation, student volunteers acted out the scene from Romeo and Juliet in which Romeo, Juliet and Paris were dead in the tomb (Romeo and Juliet, 5.3.120). Other students volunteered to play the potential suspects and witnesses. The three students in the death scene were in their places at the start of the presentation, and we then gave the audience some context through a power point slide that revealed scene details (Figure 1). The year: $\sim 1595$. The place: a tomb in Verona, Italy. The scene: one young woman and two young men dead. We asked the audience to consider this scene from a modern forensic perspective. If a crime scene investigator were arriving at this scene, he or she would be interested in knowing what happened at the scene, how each person died, whether the deaths were suicides or murders, and if and how the deaths were related. At this point in the presentation, we discussed that the first arriving officer would take steps to preserve and protect the crime scene, assist any one with immediate medical needs, detain potential suspects and witnesses, and begin the search for evidence (6). We asked the audience what observations they could make about the crime scene, and if they saw any evidence to collect. Attention was drawn to the vial in one man's hand, the dagger piercing the woman's body, and the stabbing wound in the other young man's body. Careful observation also revealed that the man with the vial had an empty dagger sheath. Could the dagger in the woman belong to 
this empty sheath? As the presenters, we acted as investigators at this point in the presentation.

We let the audience know that we were able to detain three potential suspects on the cemetery grounds, and we then asked to hear from each one. The first student volunteer suspect spoke up using the following words from Shakespeare.

Friar Laurence. I am the greatest, able to do least, Yet most suspected, as the time and place Doth make against me, of this direful murder. And here I stand, both to impeach and purge Myself condemned and myself excus'd.

...Romeo, there dead, was husband to that Juliet, And she, there dead, that Romeo's faithful wife. I married them, and their stol'n marriage day Was Tybalt's doomsday, whose untimely death Banish'd the new-made bridegroom from this city; For whom, and not for Tybalt, Juliet pin'd. You, to remove that siege of grief from her, Betroth'd and would have married her perforce To County Paris. Then comes she to me And with wild looks bid me devise some mean To rid her from this second marriage, Or in my cell there would she kill herself. Then gave I her - so tutor'd by my art A sleeping potion, which so took effect As I intended, for it wrought on her The form of death. Meantime I writ to Romeo That he should hither come as this dire night To help to take her from her borrow'd grave, Being the time the potion's force should cease. But he which bore my letter, Friar John, Was stay'd by accident, and yesternight Return'd my letter back. Then all alone At the prefixed hour of her waking Came I to take her from her kindred's vault, Meaning to keep her closely at my cell Till I conveniently could send to Romeo. But when I came, some minute ere the time Of her awakening, here untimely lay The noble Paris and true Romeo dead. She wakes; and I entreated her come forth And bear this work of heaven with patience, But then a noise did scare me from the tomb And she, too desperate, would not go with me 
But, as it seems, did violence on herself.

(Romeo and Juliet, 5.3.223-264)

We then asked the student playing the Friar to tell us more about the potion that he gave

to Juliet. The student volunteer went on to say the following words from Shakespeare that the

Friar had said to Juliet when giving her the potion, as we simultaneously presented them on a power point slide.

Friar Laurence. And this distilling liquor drink thou off;

When presently through all thy veins shall run

A cold and drowsy humour, for no pulse

Shall keep his native progress, but surcease:

No warmth, no breath shall testify thou livest,

The roses in thy lips and cheeks shall fade

To wanny ashes, thy eyes' windows fall

Like death when he shuts up the day of life.

Each part depriv'd of supple government

Shall stiff and stark and cold appear, like death,

And in this borrow'd likeness of shrunk death

Thou shalt continue two and forty hours

And then awake as from a pleasant sleep.

(Romeo and Juliet, 4.1.94-106)

We asked the other two students playing witnesses to identify themselves and to explain why they were at the scene. The student playing Balthasar, Romeo's man, spoke first. Then the student playing Paris's page spoke of his master.

Balthasar. I brought my master news of Juliet's death, And then in post he came from Mantua

To this same place, to this same monument.

This letter he early bid me give his father

And threaten'd me with death, going in the vault, If I departed not and left him there.

(Romeo and Juliet, 5.3.272-277)

Page. He came with flowers to strew his lady's grave And bid me stand aloof, and so I did.

Anon comes one with light to ope the tomb

And by and by my master drew on him, 
And then I ran away to call the Watch.

(Romeo and Juliet, 5.3.281-285)

After Balthasar handed us the letter that he mentioned, we looked it over and then told the audience that Romeo wrote that he did marry Juliet as the Friar stated, and that he heard of her death and bought a poison from an apothecary to die with Juliet in the tomb (Romeo and Juliet, 5.3.286-290). According to the Page's report that Romeo and Paris may have been fighting, it was posed to the audience that it seemed that Romeo ended up killing Paris and then taking the poison to kill himself, hence the empty vial in his hand.

We then asked the audience whether or not we had enough information to know if the Friar's story was true about Juliet. After all, she was found dead in her home and then buried by her family. A question was put forward to the audience: would a sleeping potion really lead people to believe she was dead if she wasn't? On the other hand, could it be possible that the Friar tried to murder Juliet to rid himself of the problems he had caused. The Friar might have wanted her dead so that he wouldn't be dishonored to marry her a second time ${ }^{1}$. We posed to the audience that it was possible that the Friar tried to murder Juliet with the potion, and then finding this attempt partially unsuccessful when she wound up alive in the tomb, he stabbed her with Romeo's dagger to finish the job. We explained to the audience that we would need an autopsy of Juliet's body to know for sure what caused her death and if any poison was involved. We defined the terms autopsy and forensic toxicology and presented these on a power point slide. An autopsy involves determining the cause of death through the medical dissection and examination of a body (6). Forensic toxicologists can examine body fluids and organs to determine the presence or absence of drugs and poisons using chemical methods of isolation and identification (6). 
At this point in our presentation, we had set the scene, acquired information from individuals at the scene, and generally helped the audience to consider this classic death scene from a forensic scientist's point of view. The next part of our presentation that we will describe is based on literature that indicates that Shakespeare's description of the potion given to Juliet by the Friar (quoted by the Friar above) is similar to a description by a well-known sixteenthcentury herbalist, Gerarde, of the plant, deadly nightshade (Atropa belladonna) that contains the alkaloids, hyoscine and $l$-hyoscyamine $(7,8,9)$. Therefore, after defining autopsy and forensic toxicology, we revealed that the chemicals hyoscine and atropine (racemic mixture of $d, l$ hyoscyamine that forms upon extraction of $l$-hyoscyamine from a plant source (10)) (see Figure 2) were determined to be in Juliet's body upon death. The chemical structures of these compounds were shown on a slide and we explained that they are from a class of compounds known as alkaloids defined as naturally occurring nitrogen-containing organic bases that have significant physiological effects on humans (11). Through visuals of the parasympathetic nervous system, we explained that atropine and hyoscine interfere with this system responsible for such things as contracting the smooth, involuntary muscles of the inner organs and producing gland fluids (12). Upon showing the structure of acetylcholine, we articulated that atropine and hyoscine chemically resemble this compound (see Figure 3), the neurotransmitter responsible for activating muscarinic receptors that produce changes in the cell that stimulate the physiological response of the organ. We described that atropine and hyoscine can bind to muscarinic receptors, but nerve transmission is blocked since they do not stimulate the cell (12).

Further explanation was given to indicate that atropine and hyoscine can be used for medical purposes when there is a need to inhibit the effects of the parasympathetic nervous system. Examples were presented showing that hyoscine and hyoscyamine have been used to 
treat asthma, dizziness, muscular spasms, irregular heartbeats, irritable bowel syndrome, and sea sickness. They have also been used to sedate, to dry up bodily secretions before surgery, to dilate pupils, and to kill pain during child birth (12-14). However, we stated while showing a slide titled, 'The Poison is in the Dose,' high doses cause cardiac excitement, labored breathing, feverishness and hallucinations, followed by coma, circulatory collapse and respiratory failure (12-14). In other words, we emphasized, high doses can cause a rapid, but painful death (8).

We explained to the audience that therefore, depending on the dose of these drugs found in Juliet, the Friar could have either sedated or killed Juliet. To learn more about the possibilities, we then turned to a discussion of the source of these drugs that the Friar may have had available at the time in common herbs or plants. During Shakespeare's time, in the sixteenth and seventeenth centuries, herbalists and apothecaries began to systematically study the usefulness and toxicity of plants $(9,10)$. Shakespeare probably read the popular 'Herbals' and may have even been acquainted with some of the herbalists. In fact, we told the audience, there are many references in his works to lust inducing herbs or plants (pansies, sweet potatoes, burdocks), sleep inducing herbs or plants (poppy and mandragora), and death inducing herbs or plants (nightshade, henbane, aconitum, hemlock, ratsbane, moss, mistletoe, and yew) (9).

Of the sleep inducing and death inducing plants, there are a particular set of plants in the Solanaceae family of plants (a family of plants that includes potato, tomato, and tobacco) that contain hyoscine and hyoscyamine. These are mandrake, henbane, thorn apple, and deadly nightshade. We explained to the audience that the hyoscine and atropine in these plants made them essential sources of poison, hallucinogens, and medicines in ancient times depending on the dose taken (8). After describing these plants to the audience, we then described each one in detail using visuals and images when appropriate. Mandrake (Mandragora officinarum) (Figure 
4) contains mainly hyoscine, and while the fermented root was used as a poison, it was also associated with fertility as far back as Biblical times due to the root resembling the human form. In addition, it was valued as a powerful anesthetic $(13,15)$. Shakespeare made many references to mandrake in his plays including Antony and Cleopatra, Othello, Macbeth, Henry IV, Romeo and Juliet, and Henry VI. Slides were shown with quotes from Shakespeare referencing mandrake. For instance, in Antony and Cleopatra, we showed that Cleopatra says, "Give me to drink mandragora.../That I might sleep out this great gap of time/My Antony is away." (Antony and Cleopatra, 1.5.4-7)

Next we described henbane to the audience. Henbane (Hyoscyamus niger) (Figure 5) contains about $0.15 \%$ alkaloids that are an almost equal ratio of hyoscine and hyoscyamine (14). It was used as a salve for pain, to help with insomnia, and to increase the intoxicating action of beer. In addition, mixtures of henbane and mandrake and other plants were used in witches 'flying ointments' to produce hallucinations. Such mixtures were used to produce soporific sponges to anesthetize patients $(12,16,17)$. We went on to explain that just as with mandrake, the poison is in the does with henbane. Although henbane was used for medical purposes as described above, henbane was also used as a poison in higher doses, for executions and poisonings in upper class $17^{\text {th }}$ century France. In Shakespeare's play Hamlet, the ghost of Hamlet's father speaks of hebenon (commonly thought to be another term for henbane) as the poison used to kill him (Hamlet, 1.5.59-73). We presented the Hamlet quote on a slide for the audience.

We went on to describe thorn apple (Datura stramonium) (Figure 6) which contains about $0.45 \%$ alkaloids in a ratio of $1: 2$ hyoscine : hyoscyamine (14). Small amounts of thorn apple were used as an aphrodisiac or sedative as mandrake was. In addition, it was used to treat 
mania, epilepsy, melancholy and asthma. However, American colonist discovered that it could be poisonous when they ate it in Jamestown in a time of short rations, obviously in too high of a dose (8).

Deadly nightshade (Atropa belladonna) (Figure 7), we went on to discuss, is the strongest poison of the four plants since it contains the most alkaloids ( $0.6 \%)$ and the highest proportion of hyoscyamine (20:1 hyoscyamine:hyoscine) which is known to be more toxic than hyoscine (14). Even though a single berry could cause death and was used as a poison by the wife of Emperor Augustus, Livia, and Agrippina, the wife of Claudius, deadly nightshade was still used for medicinal and cosmetic purposes in small doses (13). For instance, it was used as a sedative, antispasmodic, and to dilate pupils by Renaissance women for cosmetic purposes (13). It was also used to treat palsy, apoplexy, epilepsy, whooping cough, mania, and chronic rheumatism among other things (10).

We explained to the audience that it seemed that these four plants that would be available to the Friar could all be used to medically sedate or to kill just as the active chemical compounds, hyoscine and hyoscyamine, that they could contain depending on the dose. So, this did not help us to narrow down which plant or plants the Friar may have used in his potion. However, we described to the audience, when we consider again what the Friar said about the potion, "through all thy veins shall run/A cold and drowsy humour, for no pulse/Shall keep.../And in this borrow'd likeness of shrunk death/Thou shalt continue two and forty hours/And then awake as from a pleasant sleep," (Romeo and Juliet, 4.1.95-106) and compare it to statements made by the influential herbalist, Gerarde, we can see that one plant was the most likely source $(9,18)$. We presented quotes from Gerarde on power point slides. Gerarde said mandrake has a 'drowsie and sleeping power,' when boiled in wine to drink or when it is smelled. Gerarde said that when 
henbane is swallowed, it produces a sleep that 'is deadly to the partie.' Gerarde said of deadly nightshade, "This kinde of Nightshade causeth sleep...it bringeth such as have eaten thereof into a dead sleepe wherein many have died..." We explained to the audience that the Friar's statements seemed closest to Gerarde's description of the effects of deadly nightshade. Although Gerarde described all three as causing sleep or death, only in his description of deadly nightshade did he refer to a dead sleep and death in some cases but not all.

Therefore, using our interview of the suspect, our autopsy results, and our knowledge of available information on herbs, we concluded for the audience that the Friar made a potion for Juliet out of deadly nightshade. However, we then posed to the audience the question as to why the Friar had this herb in his possession. Would he have had a reason to have deadly nightshade on his person for medical purposes? We explained that both friars and monks are priests, and that friars lived amongst the people while monks lived in monasteries. Medieval hospitals were run by well-educated monks who focused on treating a patient's soul in addition to his or her body believing that God had ultimate authority over health and recovery. During the Middle Ages, monasteries contained medicinal herb gardens and monks tended to gardens which furnished physicians with pharmaceutical products. Physicians made medicines and prescribed courses of treatment based on empirical and theoretical bases of herbalism. Monastic medicine and hospitals had declined by the end of the Middle Ages, but, we explained, it was possible that Friar Laurence would still have some knowledge and reason for keeping nightshade for medicinal purposes (19). We then revealed to the audience that further analysis of the autopsy results showed that the amount of hyoscine and atropine was probably not enough to kill Juliet, so the Friars's story was corroborated. Based on time of death determinations, Romeo and Paris died first, so Juliet's death was an apparent stabbing suicide using Romeo's dagger. 
However, we still had one question left about Romeo that we expressed to the audience. He obtained his poison from an apothecary, but apothecaries supposedly sold medicines, so why would the apothecary have a poison to sell to Romeo? We explained that if the poison had some medicinal purpose depending on the dose like the Solanaceae plants, then it would make sense for the apothecary to carry it. The apothecary's words to Romeo, "Put this in any liquid thing you will/And drink it off and if you had the strength/Of twenty men it would dispatch you straight," (Romeo and Juliet, 5.1.77-79) indicated a quick poison. We shared with the audience that an autopsy of Romeo showed that the chemical compound, aconitine, was ingested before death and we displayed the structure of this compound on a slide (Figure 8). Aconitine could come from the plant, monkshood (Aconitum napellus) (Figure 9). Gerarde stated that all aconite species are "deadly to man, likewise to all other living creatures" $(9,18)$. However, even, this very deadly herb did have medicinal uses for treatment of fever and pain when applied externally, so it would make sense than an apothecary might carry it $(10,20)$. We revealed that the effects of Aconitum napellus have also been referred to by Shakespeare in Henry IV, "King Henry ...though it do work as strong/As aconitum..." (2 Henry IV, 4.4.49-50).

Having solved much of the mystery behind the deaths of Romeo, Juliet and Paris, we then told the audience that while we may think, today, that plant based medicines are weak or not effective, people in Shakespeare's time were well aware of the power of plants. We then presented the following quote as our final slide.

Friar Laurence. O, mickle is the powerful grace that lies In plants, herbs, stones, and their true qualities. For naught so vile that on the earth doth live But to the earth some special good doth give; Nor aught so good but, strain'd from that fair use, Revolts from true birth, stumbling on abuse. Virtue itself turns vice being misapplied, 
And vice sometime's by action dignified.

Within the infant rind of this weak flower

Poison hath residence, and medicine power:

For this, being smelt, with that part cheers each part;

Being tasted, stays all sense with the heart.

(Romeo and Juliet, 2.3.11-22)

We concluded that if only Romeo had known of the importance of dosage and that it was possible for Juliet to have been alive when he found her in the tomb, things may have turned out differently. We stated, unfortunately, 'never was a story of more woe/Than this of Juliet and her Romeo'(Romeo and Juliet, 5.3.309-310). This concluded our presentation.

Using information on the chemistry and herbalism in Shakespeare's Romeo and Juliet as presented in our single lecture just described, we were able to walk the audience through answering many of the questions about the final death scene of Romeo and Juliet from a crime scene investigator's perspective. In the process, we introduced the audience to basic forensic, chemical and pharmacological concepts. As mentioned above, this material may be expanded for use in chemistry or theatre courses in a variety of ways. Using the story of Romeo and Juliet to teach chemistry, forensics, or pharmacology either in a course or as a single presentation will leave a lasting impression on an audience of non-science and science students alike. It is this new twist on an old story that can help draw students in, get them excited about science, and help them make connections across the disciplines.

\section{Acknowledgments}

We would like to thank Professor Martha S. LoMonaco, R \& J project head, and Kerry Davies '11, project intern for the opportunity to participate in the Fairfield University R \& J project that 
resulted in this manuscript. Thank you also to Professor LoMonaco, Professor Matthew Kubasik, and Professor Alison Kris for helpful suggestions during the revision of this article.

\section{Supporting Information}

A pdf version of the power point presentation that this manuscript is based on is available via the Internet at http://pubs.acs.org.

Figures

\section{Year: $\sim 1595$}

\section{Place: Tomb in Verona, Italy}

\section{Scene: One young woman and two young men dead at the scene}

Figure 1. Example power point slide from presentation introducing the audience to the final death scene of Romeo and Juliet from a modern crime scene investigator's perspective.

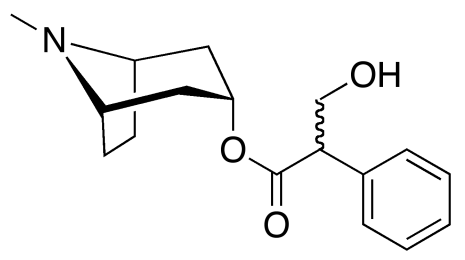

atropine<smiles>CN1[C@H]2CC[C@@H]1CC(OC(=O)C(CO)c1ccccc1)C2</smiles>

hyoscine

Figure 2. Chemical structures of atropine and hyoscine. 
<smiles>CC(=O)OCC[N+](C)(C)C</smiles>

acetylcholine

Figure 3. Chemical structure of acetylcholine.

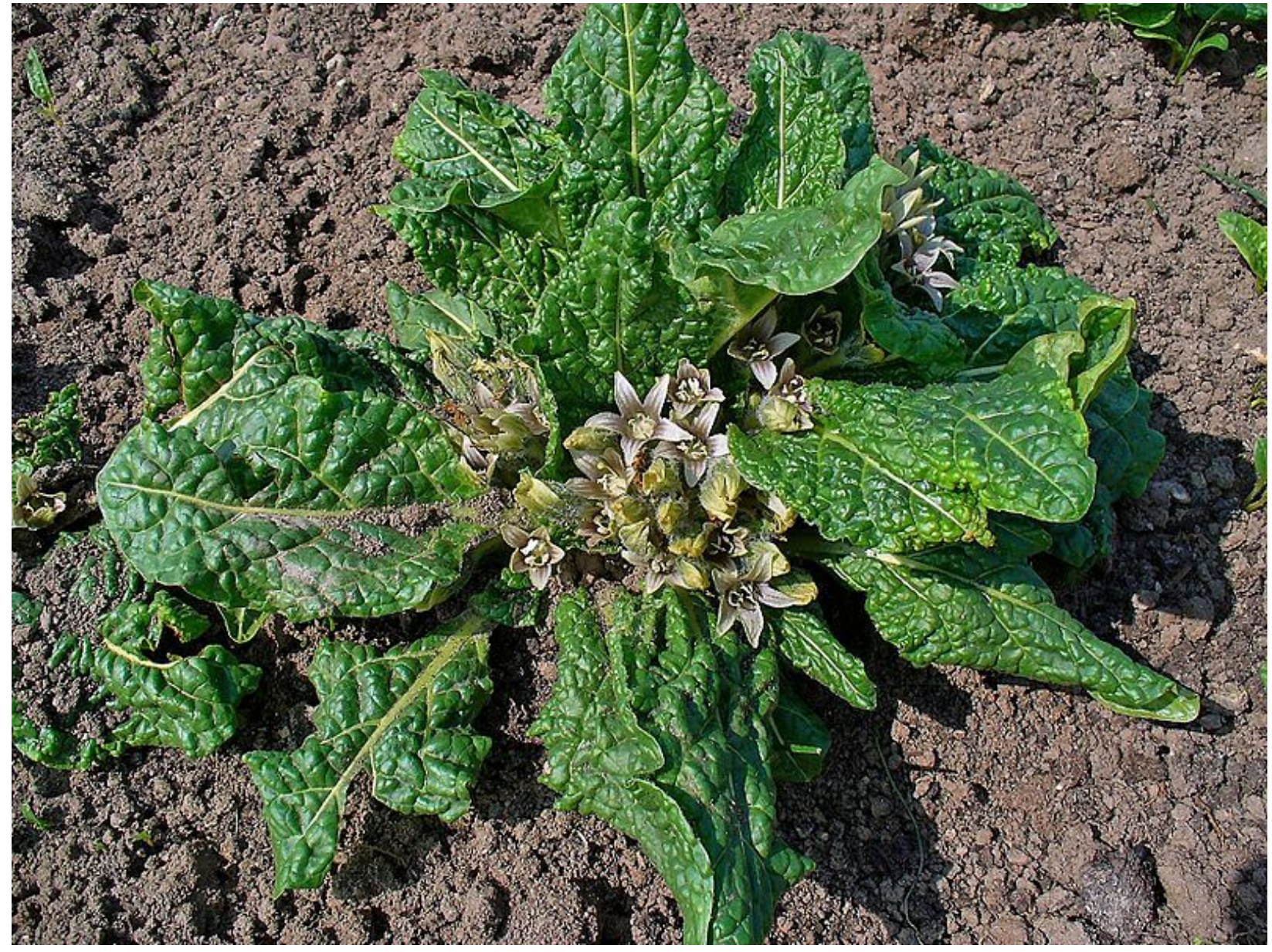

Figure 4. Mandrake (Mandragora officinarum) (reprinted from H. Zell, Wikimedia Commons (April 4, 2009)). 


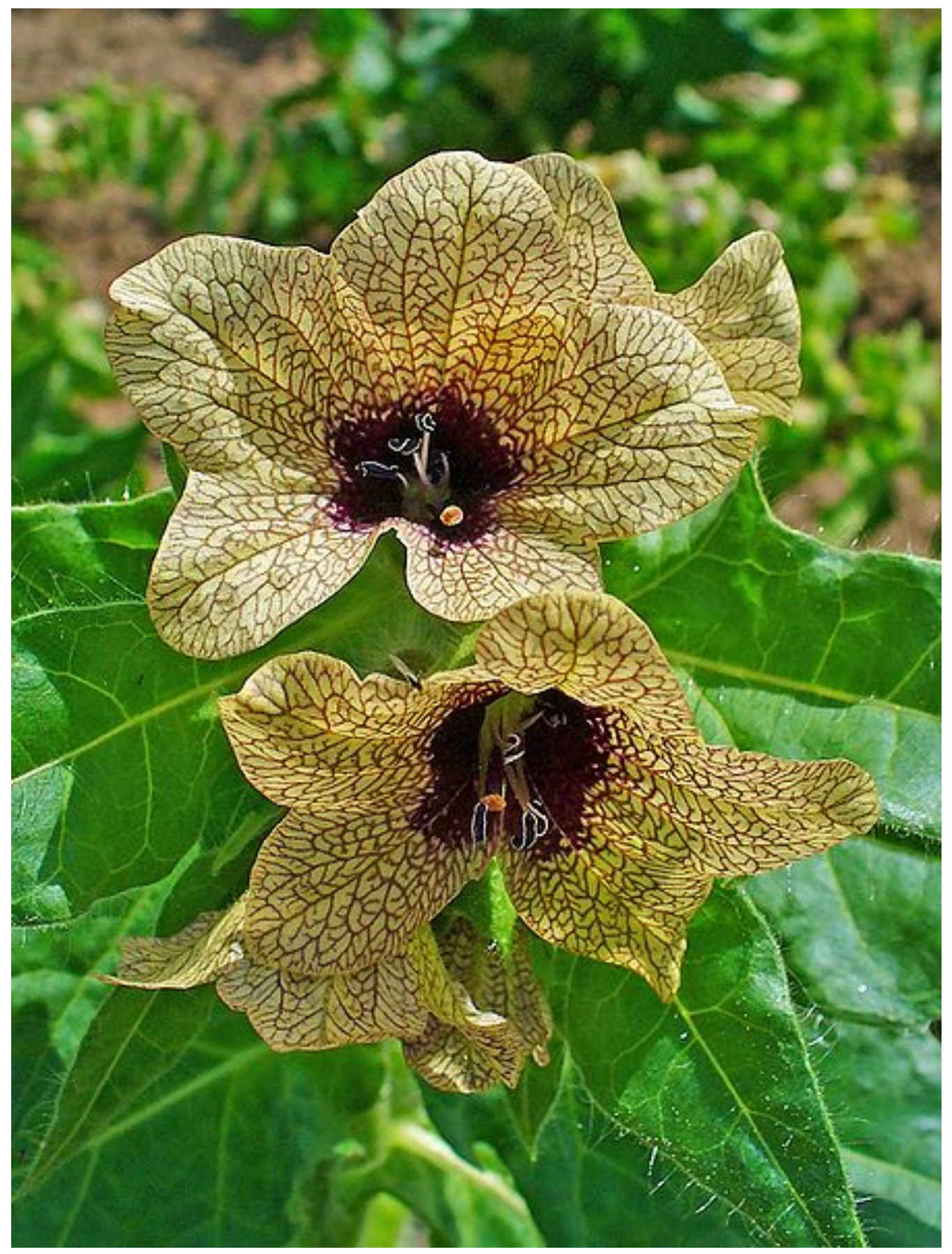

Figure 5. Henbane (Hyoscyamus niger) (reprinted from H. Zell, Wikimedia Commons (June 21, 2009)). 


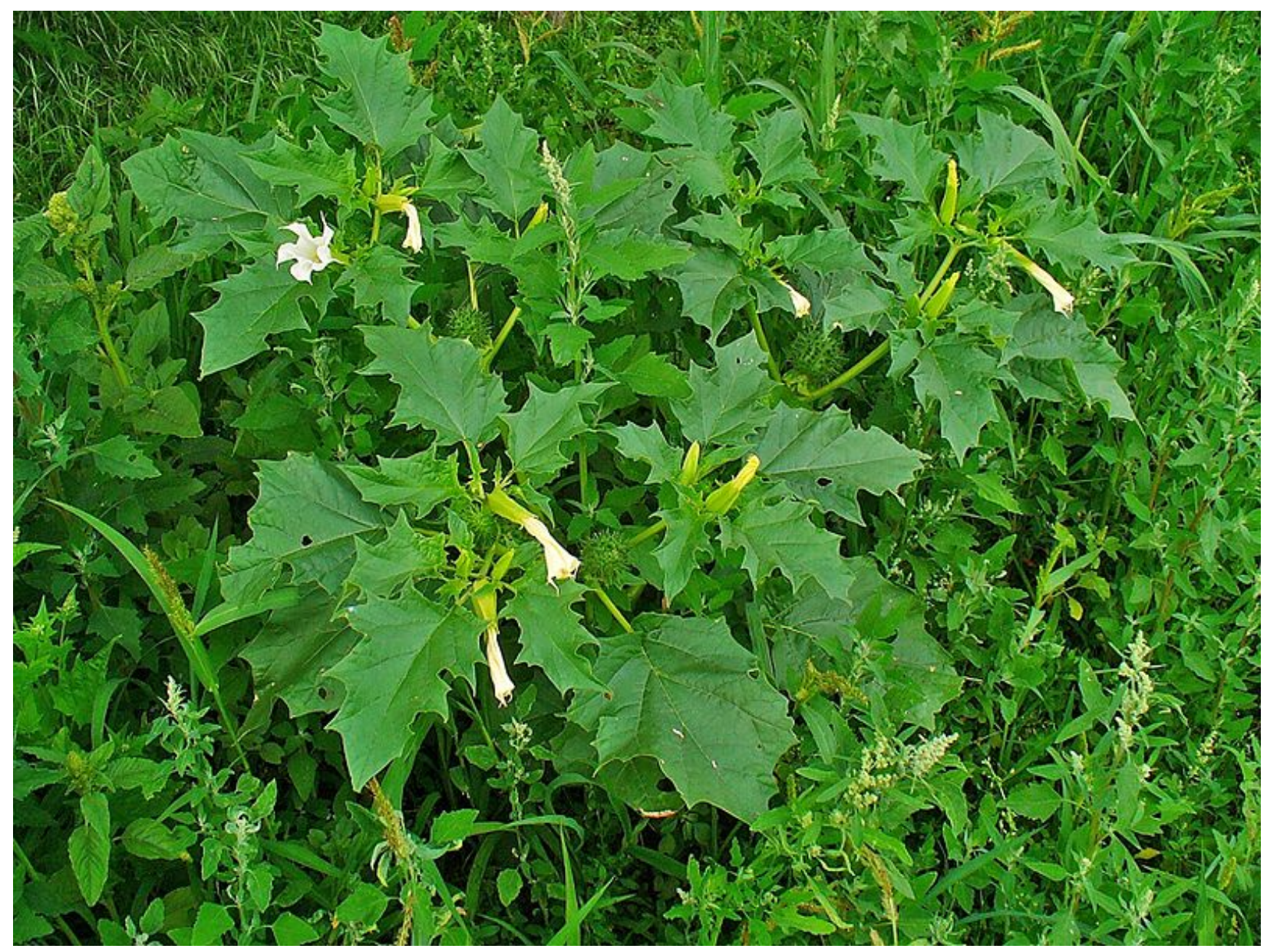

Figure 6. Thorn apple (Datura stramonium) (reprinted from H. Zell, Wikimedia Commons (June 20, 2009)). 


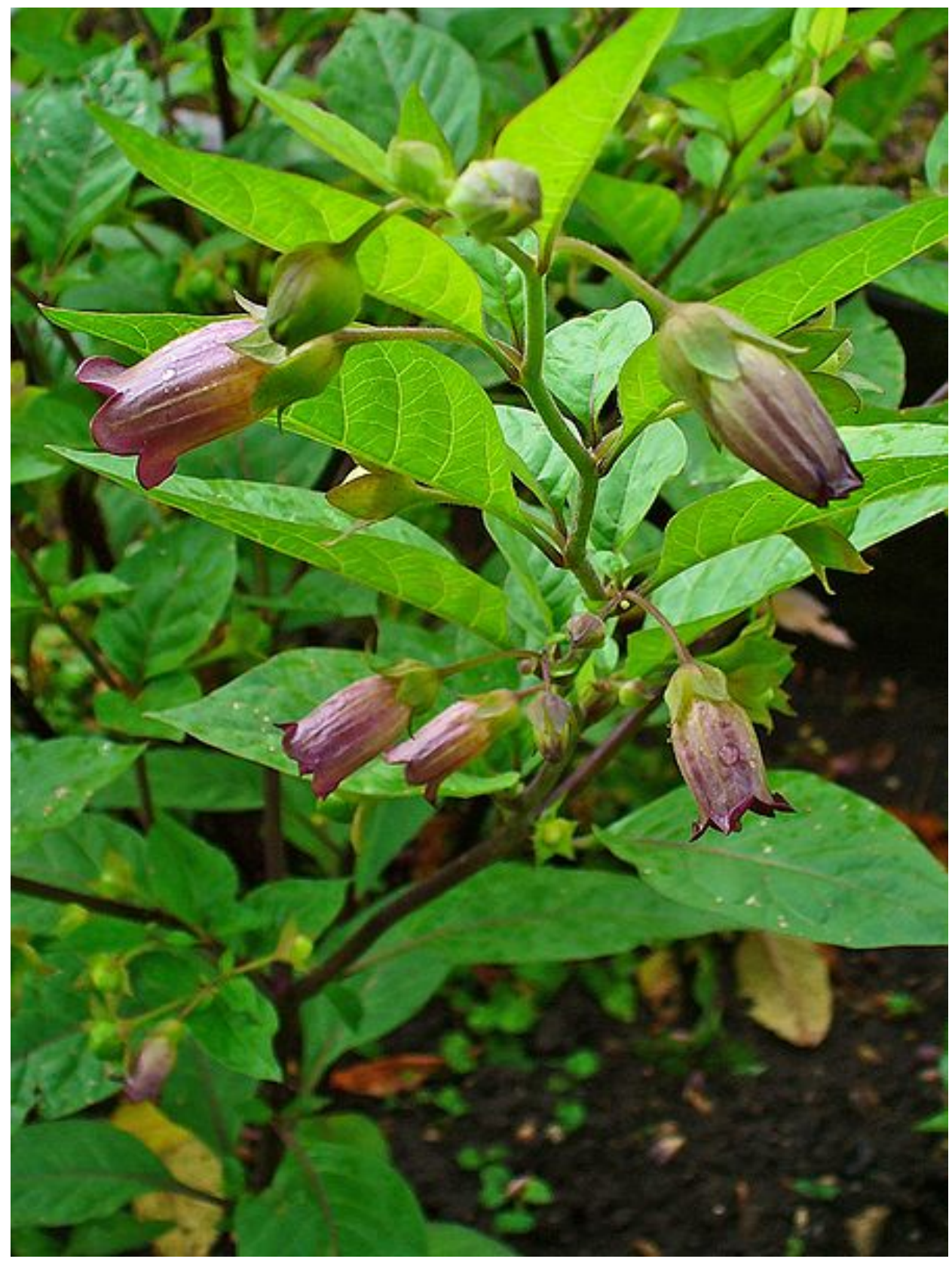

Figure 7. Deadly nightshade (Atropa belladonna) (reprinted from H. Zell, Wikimedia Commons (June 7, 2009)). 


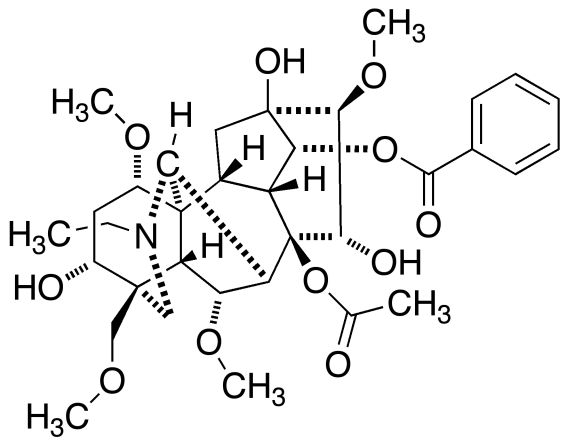

aconitine

Figure 8. Chemical structure of aconitine. 


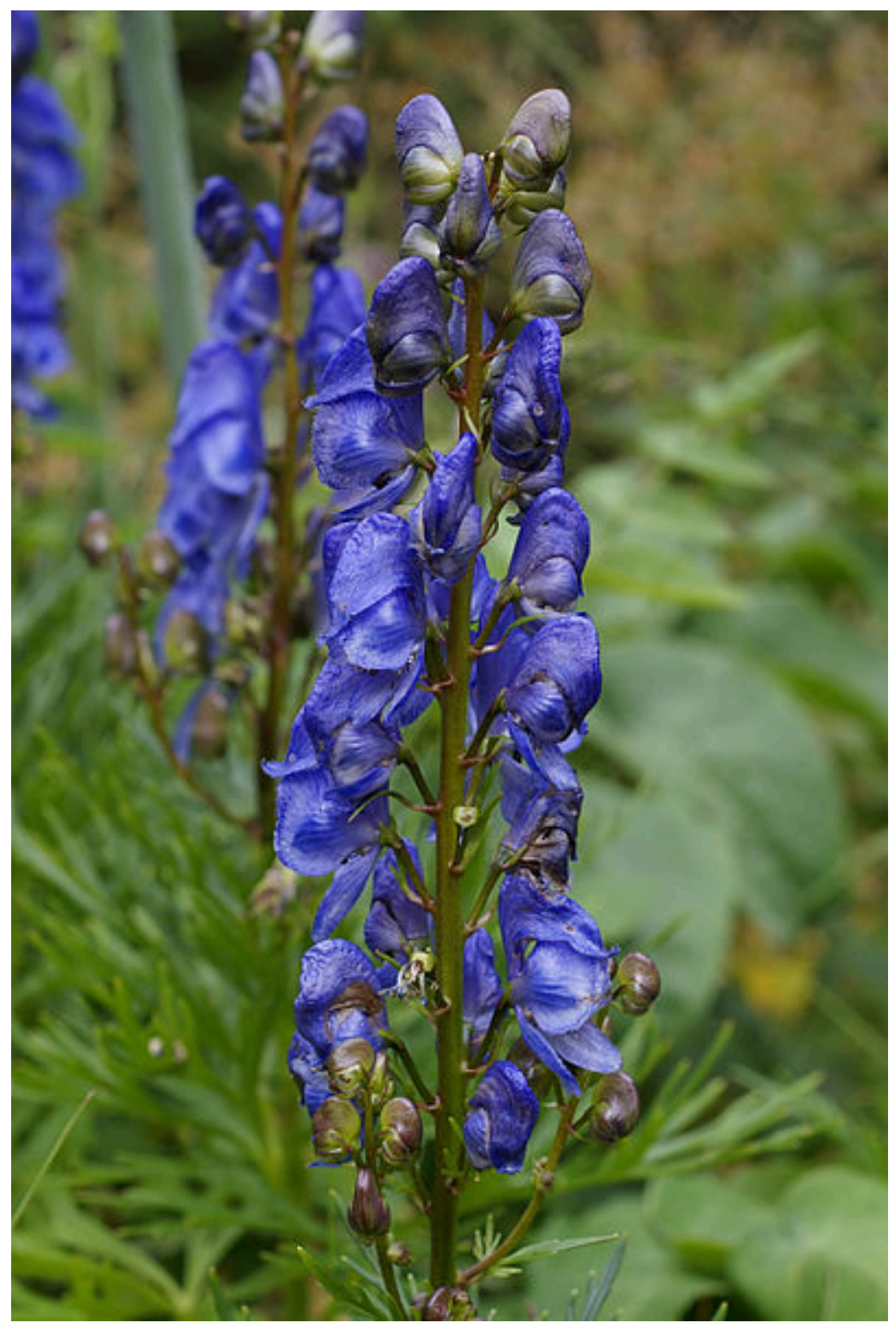

Figure 9. Monkshood (Aconitum napellus) (reprinted from Hans Hillewaert, Wikimedia Commons (August 16, 2007)). 


\section{Notes}

1. Juliet herself worried of the possibility of the Friar giving her a poison instead of a sleeping potion, "What if it be a poison which the Friar/Subtly hath minister'd to have me dead,/Lest in this marriage he should be dishonour'd,/Because he married me before to Romeo?"(Romeo and Juliet, 4.3.24-27).

\section{Literature Cited}

1. O’Shaughnessy, T. Fairfield Magazine 2010, 33, 22-27.

2. Folino, D. A. J. Chem. Educ. 2001, 78, 1615-1618.

3. Kitson, T. M. J. Chem. Educ. 2005, 82, 1504.

4. Jacobsen, E. K.; Slocum, L. E. J. Chem. Educ. 2011, 88, 366-367.

5. Waddell, T. G.; Rybolt, T. R. J. Chem. Educ. 2011, 88; DOE: 10.1021/ed101190d.

6. Saferstein, R. Criminalistics: An Introduction to Forensic Science, $10^{\text {th }}$ Ed.; Prentice Hall: New York, 2011.

7. Le Couteur, P.; Burreson, J. Napoleon's Buttons: 17 Molecules That Changed History; Penguin Group (USA) Inc: New York, 2003; p 233.

8. Mann. J. Murder, Magic and Medicine; Oxford University Press: Oxford, 1994.

9. Tabor, E. Economic Botany 1970, 24, 81-94.

10. Lee, M. R. J. R. Coll. Physicians Edinb. 2007, 37, 77-84.

11. Fox, M. A.; Whitesell, J. K. Organic Chemistry, 2nd ed.; Jones and Bartlett: Sudbury, MA, 1997; p 18-23-18-25.

12. Börsch-Haubold, A. Science in School 2007, (4), 50-55.

13. Emsley, J. Molecules of Murder: Criminal Molecules and Classic Cases; RSC Publishing: Cambridge UK, 2008. 
14. Todd Caldecott. Todd Caldecott Henbane.

http://www.toddcaldecott.com/index.php/herbs/learning-herbs/359-henbane (accessed April 6, 2011).

15. Lee, M. R. J. R. Coll. Physicians Edinb. 2006, 36, 278-285.

16. Lee, M. R. J. R. Coll. Physicians Edinb. 2006, 36, 366-373.

17. Carter, A. J. BMJ 1996, 313, 1630-1632.

18. Gerarde, J. The Herball or General Historie of Plantes (The Arnold Arboretum Copy, Houghton Library); London, 1597.

19. Silverman, B.C. HURJ, 2002, Spring 2002, 10-17.

20. Curry, S. The Pharmaceutical Journal 2005, 275, 781-783. 